\title{
TERAPI KOMPLEMENTER DALAM MENGATASI ISPA PADA IBU YANG MEMILIKI BALITA DI DUSUN SETAN DESA MAGUWOHARJO, KELURAHAN DEPOK, KABUPATEN SLEMAN
}

\author{
Ester Ratnaningsih ${ }^{1}$, Nita Ivana Benggu ${ }^{2}$ \\ 1.Prodi Pendidikan Profesi Bidan Universitas Respati Yogyakarta \\ Email: esteratna@gmail.com \\ ${ }^{2}$.Mahasiswa Prodi Pendidikan Profesi Bidan Universitas Respati Yogyakarta
}

\begin{abstract}
ABSTRAK
Terapi komplementer merupakan pelayanan pengobatan dengan menggunakan cara, alat, atau bahan yang tidak termasuk dalam standar pengobatan konvensional sebagai pelengkap pengobatan konvensional. Saat ini masyarakat lebih memilih terapi komplementer dalam mengatasi masalah kesehatan termasuk salah satunya ISPA pada balita. Terapi komplementer untuk mengatasi ISPA pada balita antara lain dengan terapi pijat, terapi uap dan pengobatan farmakologi jamu (larutan jahe dan jeruk nipis). Tujuan Penelitian ini untuk mengetahui penggunaan terapi komplementer dalam mengatasi ISPA pada balita di Dukuh Setan, Maguwoharjo, Kabupaten Sleman. Desain penelitian deskriptif, dengan teknik pengambilan convenience sampling. Pengumpulan data dilakukan pada tanggal 22- 31 Desember 2019. Hasil penelitian dari 32 responden, menunjukkan sebanyak $81,2 \%$ responden menggunakan terapi komplementer saat balita mengalami ISPA, dengan pemilihan terapi terbanyak adalah terapi pijat secara tunggal sebesar $25 \%$ dan secara kombinasi sebesar 73, $1 \%$. Cara penggunaan terapi komplementer tidak ada aturan yang pasti, hanya ketika balita mengalami ISPA diberikan sesuai kebutuhan hingga sembuh. Mayoritas alasan menggunakan terapi komplementer adalah faktor turun temurun dalam keluarga sebanyak 42,3\%. Diharapkan bagi peneliti selanjutnya menggunakan desain kualitatif untuk mengkaji lebih dalam penggunaan terapi komplementer dalam mengatasi ISPA di masyarakat.
\end{abstract}

Kata Kunci: Terapi Komplementer, ISPA, Balita

\begin{abstract}
Complementary therapy is a treatment service which uses methods, tools, or materials that are not included in conventional treatment standards as a complement to conventional medicine. Currently, the public prefers complementary therapy in managing health problems including ARI among infants. Complementary therapies to manage ARI among infants include massage therapy, steam therapy and herbal pharmacological treatment (ginger and lime solution). This study aims to determine the use of complementary therapy to manage ARI amongthe mothers of under-five children in SetanHamlet, Maguwoharjo Village, SlemanDistrict. This was a descriptive study. The samples were collected using convenience sampling technique. Data collection was carried out on 22-31December 2019. The results showed that of 32 respondents $81.2 \%$ of respondents used complementary therapy when the child experienced ARI. The therapeutic treatment mostly used was a single massage therapy of $25 \%$ and combination treatment of $73.1 \%$. There are no definitive rulesin applying complementary therapy. The mother only provided treatment when the child experienced as needed until the child was healed. The majority of respondents applied complementary therapy due to a hereditary factor (habit) in the family of $42.3 \%$. It is expected that future researchers will apply qualitative design to conduct an in-depth study on the use of complementary therapies in dealing with ARI in the community.
\end{abstract}

Keywords: Complementary Therapy, ARI, Toddler 


\section{PENDAHULUAN}

Infeksi Saluran Pernapasan Akut (ISPA) adalah semua penyakit saluran pernapasan atas atau bawah yang akut dan disebabkan oleh agen infeksius, berupa virus dan bakteri. Gejala yang timbul meliputi demam, batuk, nyeri tenggorok, coryza (pilek), suara serak, dan dapat pula disertai sesak napas, mengi, atau kesulitan bernapas (Bezerra, 2011). ISPA pada anak dibawah usia lima tahun masih menjadi masih menjadi salah satu penyebab kunjungan ke rumah sakit (Pavia AT, 2011). ISPA juga menjadi penyebab utama morbiditas dan mortalitas balita di dunia. World Health Organization (WHO) memperkirakan insidensi ISPA pada usia balita di negara berkembang adalah sekitar $15 \%$ pertahun, sedangkan di Indonesia sekitar $17 \%$.

Berdasarkan hasil SDKI tahun 2017 persentase balita yang memiliki gejala infeksi saluran pernapasan akut (ISPA) di Yogyakarta sebesar 2,6\% dari 213 balita. Angka ini lebih tinggi dari provinsi Jawa Tengah dengan persentase 2,3 \% dari 1989 balita (SDKI 2017). Profil kesehatan Kabupaten Sleman tahun 2018 menunjukkan pola penyakit yang sering terjadi di puskesmas untuk semua golongan umur, kasus penyakit yang paling tinggi adalah kasus common cold (pilek) yakni sebanyak 78.995 kasus menurun dari tahun sebelumnya yang berjumlah 86.350 kasus (Profil Kesehatan Dinkes Sleman, 2018)

Saat ini salah satu penyakit ISPA yang perlu mendapat perhatian adalah penyakit influenza, karena merupakan penyakit yang dapat menimbulkan wabah, sesuai dengan Permenkes Nomor 1501/Menkes/Per/X/2010 tentang Jenis Penyakit Menular Tertentu yang dapat Menimbulkan Wabah dan Upaya Penanggulangan. Dalam mengatasi ISPA khususnya ISPA yang menyerang saluran pernapasan bagian atas seperti batuk, dermam, pilek, masyarakat memilih untuk menggunakan atau menyertai terapi lain selain terapi konvensional, yaitu terapi komplementer.

Saat ini banyak masyarakat yang menggunakan obat herbal atau terapi relaksasi dalam mengatasi ISPA seperti mengonsumsi jeruk nipis yang dicampur dengan kecap yang dipercaya dapat melegakan tenggorokan dan mengurangi batuk. Ada juga yang melakukan pijat atau massage dengan minyak esensial.
Pemberian madu juga merupakan adalah salah satu terapi komplementer yang dapat digunakan untuk membantu meredakan batuk pada malam hari. Madu dapat diberikan kepada anak karena aman dan efektif menurunkan skor frekuensi batuk dan meningkatkan kualitas tidur anak seperti yang dijelaskan oleh Evans, Tuleu, dan Sutcliffe (2010), pengobatan dengan madu efektif untuk batukdan tidur anak. Penelitian oleh Shadkam, Mozafari-Khosravi, dan Mazayan (2010) menyebutkan bahwa madu dapat mengontrol batuk, lebih murah, mudah didapatkan dan aman untuk anak-anak.

Terkait dengan dikembangkannya terapi komplementer, berdasarkan hasil SDKI 2017 pengobatan anak dengan gejala ISPA sebanyak $10,8 \%$ melakukan pengobatan lainnya selain ke fasilitas kesehatan seperti Puskesmas, Rumah Sakit atau klinik. Dari 10,8 \% tersebut salah satunya adalah dengan melakukan terapi pengobatan alternatif komplementer. Pengobatan alternative tradisional masih sering digunakan di wilayah pedesaan maupun perkotaan. Hal ini disebabkan karena faktor budaya, tradisi, dan pengetahuan tentang penyembuhan penyakit (Amir dan Hanafiah, 2009).

Survey yang dilakukan pada $10 \mathrm{Ibu}$ balita yang datang ke Posyandu di Dusun Setan pada 22 September 2019 tentang penggunaan terapi komplementer selain terapi konvensional didapati bahwa sebanyak $7 \mathrm{ibu}$ menggunakan terapi komplementer untuk mengatasi ISPA. Terapi komplementer yang biasa digunakan adalah larutan jeruk nipis dan kecap serta pemberian minyak kayu putih. Berdasarkan banyaknya terapi komplementer yang ditawarkan khususnya untuk pasien ISPA dan banyaknya jumlah balita yang mengalami ISPA, peneliti tertarik untuk melakukan penelitian dengan judul "Terapi komplementer dalam mengatasi ISPA pada ibu yang memiliki balita di Dusun Setan, Desa Maguwoharjo, Kecamatan Depok, Kabupaten Sleman". METODE

Desain penelitian yang digunakan adalah deskriptif, dengan variabel terapi komplementer yang digunakan keluarga dalam mengatasi ISPA pada balita. Karakteristik responden yang diteliti antara lain : umur ibu, pendidikan terakhir, suku bangsa, pekerjaan dan penghasilan ibu. 
Populasi dalam penelitian ini adalah ibu yang memiliki anak balita di Dusun Setan, Desa Maguwoharjo, Kecamatan Depok, Kabupaten Sleman, Daerah Istimewa Yogyakarta yang anaknya pernah mengalami ISPA yaitu sebanyak 57 orang responden. Teknik pengambilan sampel yang digunakan dalam penelitian ini adalah dengan teknik convenience sampling. Jumlah sampel yang memenuhi syarat dan bersedia menjadi responden sebanyak 32 orang dan waktu pengumpulan data dilakukan pada tanggal 22 sampai 30 Desember 2019.

Alat yang digunakan dalam penelitian ini adalah kuesioner data demografi, kuesioner terapi komplementer yang digunakan keluarga dalam mengatasi ISPA pada balita. Data dianalisis secara univariat dengan menggunakan distribusi frekuensi dan persentase. Variabel dianalisis secara univariat dalam penelitian ini adalah umur ibu, pendidikan terakhir, suku bangsa, pekerjaan dan penghasilan ibu, terapi komplementer yang digunakan keluarga dalam mengatasi ISPA pada balita, penggunaan terapi komplementer pada setiap terapi dan alasan keluarga memilih terapi komplementer.

\section{HASIL}

\section{Karakteristik Responden}

Responden yang terlibat di dalam penelitian ini merupakan ibu Balita usia 1-5 tahun yang berada di Dukuh sebanyak 32 orang. Ibu Balita di Dukuh Setan, Desa Maguwoharjo, Kecamatan Depok, Kabupaten Sleman yang menjadi responden penelitian ini memiliki berbagai karakteristik. Tabel 1 menunjukkan sebaran responden berdasarkan karakteristik umur ibu, pendidikan terakhir, suku bangsa, pekerjaan dan penghasilan ibu.

\section{Tabel 1 Distribusi Frekuensi dan Persentase Data Demografi Responden}

$(\mathbf{n}=32)$

\begin{tabular}{|c|c|c|}
\hline Data Demografi & $\mathbf{N}$ & Persentase \\
\hline \multicolumn{3}{|l|}{ Umur } \\
\hline$<20$ tahun & 2 & $6,2 \%$ \\
\hline $20-25$ tahun & 6 & $18,8 \%$ \\
\hline 26-30 tahun & 11 & $34,4 \%$ \\
\hline 31-35 tahun & 6 & $18,8 \%$ \\
\hline$>35$ tahun & 7 & $21,9 \%$ \\
\hline \multicolumn{3}{|l|}{ Tingkat Pendidikan } \\
\hline Rendah (SD, SMP) & 7 & $21,9 \%$ \\
\hline Menengah (SMA) & 16 & $50 \%$ \\
\hline Tinggi (Perguruan & 9 & $28,1 \%$ \\
\hline \multicolumn{3}{|l|}{ Tinggi) } \\
\hline \multicolumn{3}{|l|}{ Status Pekerjaan Ibu } \\
\hline Bekerja & 24 & $75 \%$ \\
\hline Tidak Bekerja & 8 & $25 \%$ \\
\hline \multicolumn{3}{|l|}{ Suku Bangsa } \\
\hline Jawa & 28 & $87,4 \%$ \\
\hline Sunda & 4 & $12,5 \%$ \\
\hline \multicolumn{3}{|l|}{ Penghasilan Ibu per bulan } \\
\hline$<\mathrm{UMR}$ & 25 & $78,1 \%$ \\
\hline$\geq \mathrm{UMR}$ & 7 & $21,9 \%$ \\
\hline
\end{tabular}

Berdasarkan kelompok umur, kelompok umur ibu dengan usia 26 -30 tahun adalah kelompok umur terbanyak jumlahnya, yaitu 11 orang $(34,4 \%)$ dari total 32 orang responden. Berdasarkan tingkat pendidikan, maka terbanyak adalah pendidikan terakhir menengah (SMA), yaitu 16 orang (50\%). Berdasarkan status pekerjaan, ibu tidak bekerja atau sebagai ibu rumah tangga adalah yang terbanyak, yaitu 24 orang (75\%). Berdasarkan suku bangsa terbanyak adalah suku Jawa yaitu 28 orang ( 87,4 \%). Berdasarkan penghasilan ibu per bulan dari total $32 \mathrm{ibu}$ hanya 7 $(21,9 \%)$ yang memiliki penghasilan $\geq$ UMR Kabupaten Sleman Tahun 2019 yaitu sebesar Rp.1.701.000,-

\section{Analisis Univariat}


a. Terapi Komplementer yang digunakan Keluarga dalam Mengatasi ISPA pada Balita

Hasil analisa data untuk pemilihan terapi komplementer yang digunakan keluarga dalam

Tabel 2 Distribusi Frekuensi dan Persentase Penggunaan Terapi Komplementer dalam Mengatasi ISPA pada Balita $(n=32)$

\begin{tabular}{|c|c|c|}
\hline $\begin{array}{c}\text { Penggunaan } \\
\text { Terapi } \\
\text { Komplementer }\end{array}$ & $\mathbf{N}$ & $\begin{array}{c}\text { Persentase } \\
(\%)\end{array}$ \\
\hline $\begin{array}{ll}\text { Menggunakan } \\
\text { Terapi } \\
\text { Komplemente }\end{array}$ & 26 & $81,2 \%$ \\
\hline & 6 & $18,8 \%$ \\
\hline Total & 32 & $100 \%$ \\
\hline $\begin{array}{l}\text { Hasil penel } \\
\text { sebagian besar ib } \\
\text { Dukuh Setan }\end{array}$ & $\begin{array}{l}\text { hwa } \\
\text { a di } \\
\text { erapi }\end{array}$ & $\begin{array}{l}\text { anak yaitu sebesar } 81,2 \% \text {. Rincian mengenai } \\
\text { sebaran pemilihan terapi komplementer dalam } \\
\text { mengatasi ISPA pada ibu yang memiliki balita } \\
\text { dapat dilihat pada tabel } 3 \text { berikut. }\end{array}$ \\
\hline
\end{tabular}

mengatasi ISPA pada 32 orang responden dapat dilihat pada Tabel 2 berikut ini.

komplementer dalam mengatasi ISPA pada

Tabel 3. Distribusi frekuensi pemilihan terapi komplementer dalam mengatasi ISPA pada keluarga yang memiliki balita $(n=32)$

\begin{tabular}{l}
\hline \multicolumn{1}{c}{ Pernyataan } \\
\hline Tidak Menggunakan \\
Larutan Jahe dan Madu \\
Larutan Jeruk nipis dan Kecap \\
Pijat \\
Terapi Uap \\
Kombinasi \\
\hline Total \\
\hline
\end{tabular}

Hasil penelitian menunjukkan bahwa dari 26 ibu yang menggunakan terapi komplementer untuk mangatasi ISPA pada balita sebagian besar menggunakan terapi komplementer kombinasi sebesar 37,5 \%,

\begin{tabular}{lc}
$\mathbf{N}$ & Persentasi (\%) \\
\hline 6 & $18,8 \%$ \\
1 & $3,1 \%$ \\
1 & $3,1 \%$ \\
8 & $25 \%$ \\
4 & $12,5 \%$ \\
12 & $37,5 \%$ \\
\hline 32 & $100 \%$ \\
\hline & dan sebanyak 25 \% responden menggunakan \\
& pijat untuk mengatasi ISPA pada anak.
\end{tabular}

\section{b. Penggunaan Terapi Komplementer Pada Setiap Terapi}

1) Larutan Jahe dan Madu 
Tabel 4. Distribusi frekuensi penggunaan terapi larutan jahe madu (n=10)

\begin{tabular}{|c|c|c|}
\hline $\begin{array}{l}\text { Penggunaan Terapi Larutan Jahe } \\
\text { Madu }\end{array}$ & $\mathbf{N}$ & Persentase (\%) \\
\hline $\begin{array}{l}\text { 1. Ibu memberikan terapi jahe } \\
\text { madu setiap anak batuk } \\
\text { - Ya }\end{array}$ & & \\
\hline - $\quad$ Tidak Selalu & 1 & $10 \%$ \\
\hline $\begin{array}{l}\text { 2. Frekuensi dalam sehari } \\
-\quad 3 x \text { sehari }\end{array}$ & 9 & $90 \%$ \\
\hline$-\quad<3 \times$ sehari & 3 & $30 \%$ \\
\hline $\begin{array}{l}\text { 3. Dosis setiap pemberian } \\
-\quad 1 \text { sendok teh }\end{array}$ & 7 & $70 \%$ \\
\hline $\begin{array}{l}\text { 4. Kombinasi terapi yang lain } \\
\text { selain terapi jahe madu } \\
\text { - Ya } \\
-\quad \text { Tidak }\end{array}$ & 10 & $100 \%$ \\
\hline & 9 & $90 \%$ \\
\hline & 1 & $10 \%$ \\
\hline
\end{tabular}
dari 10 ibu yang menggunakan terapi larutan jahe dan madu untuk mangatasi ISPA pada anak sebesar 70\%

2) Larutan Jeruk dan Kecap

Tabel 5. Distribusi frekuensi penggunaan terapi Jeruk dan Kecap

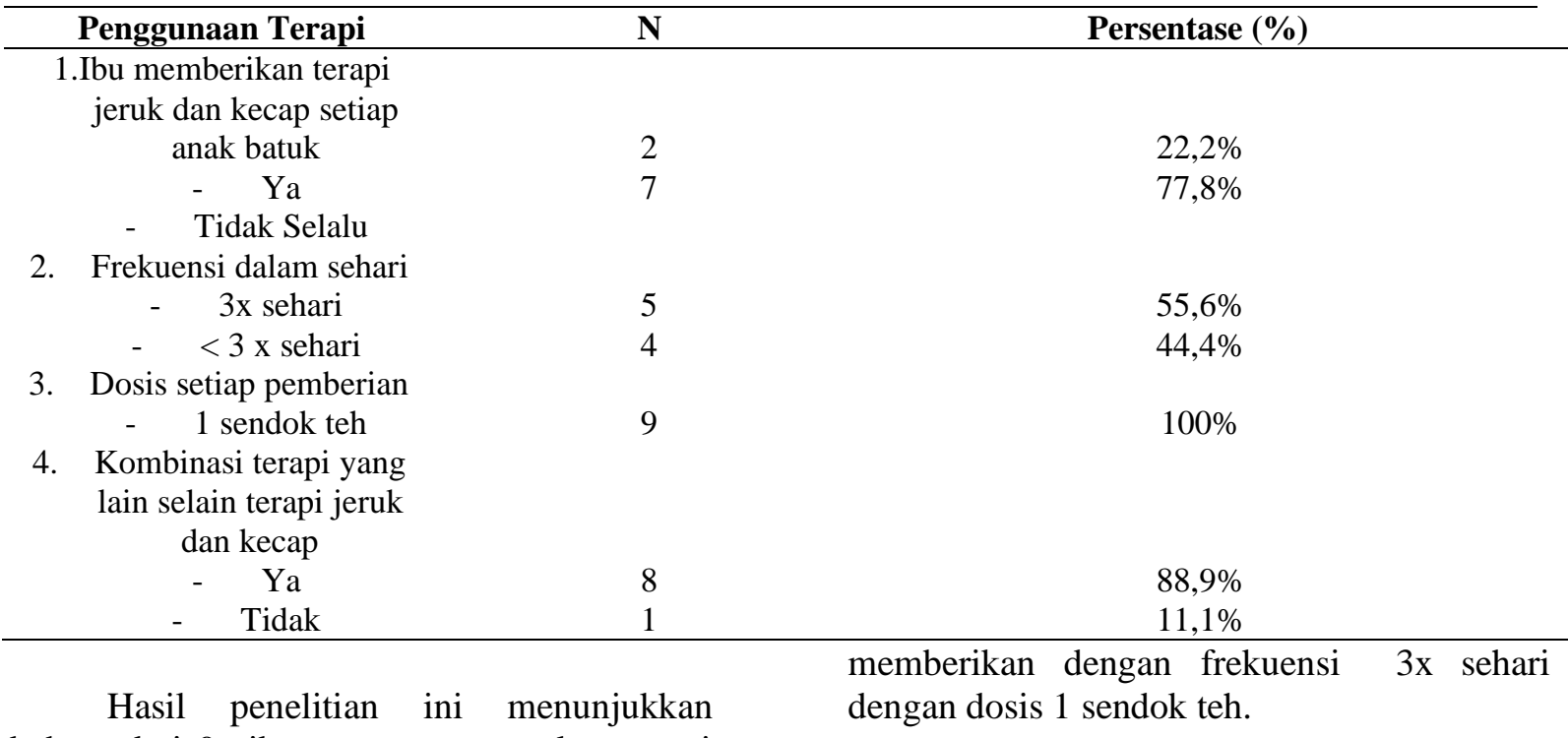

bahwa dari 9 ibu yang menggunakan terapi komplementer larutan jeruk dan kecap untuk mangatasi ISPA pada anak sebanyak $55,6 \%$

\section{3) Pijat}


Tabel 6. Distribusi frekuensi penggunaan terapi pijat $(n=19)$

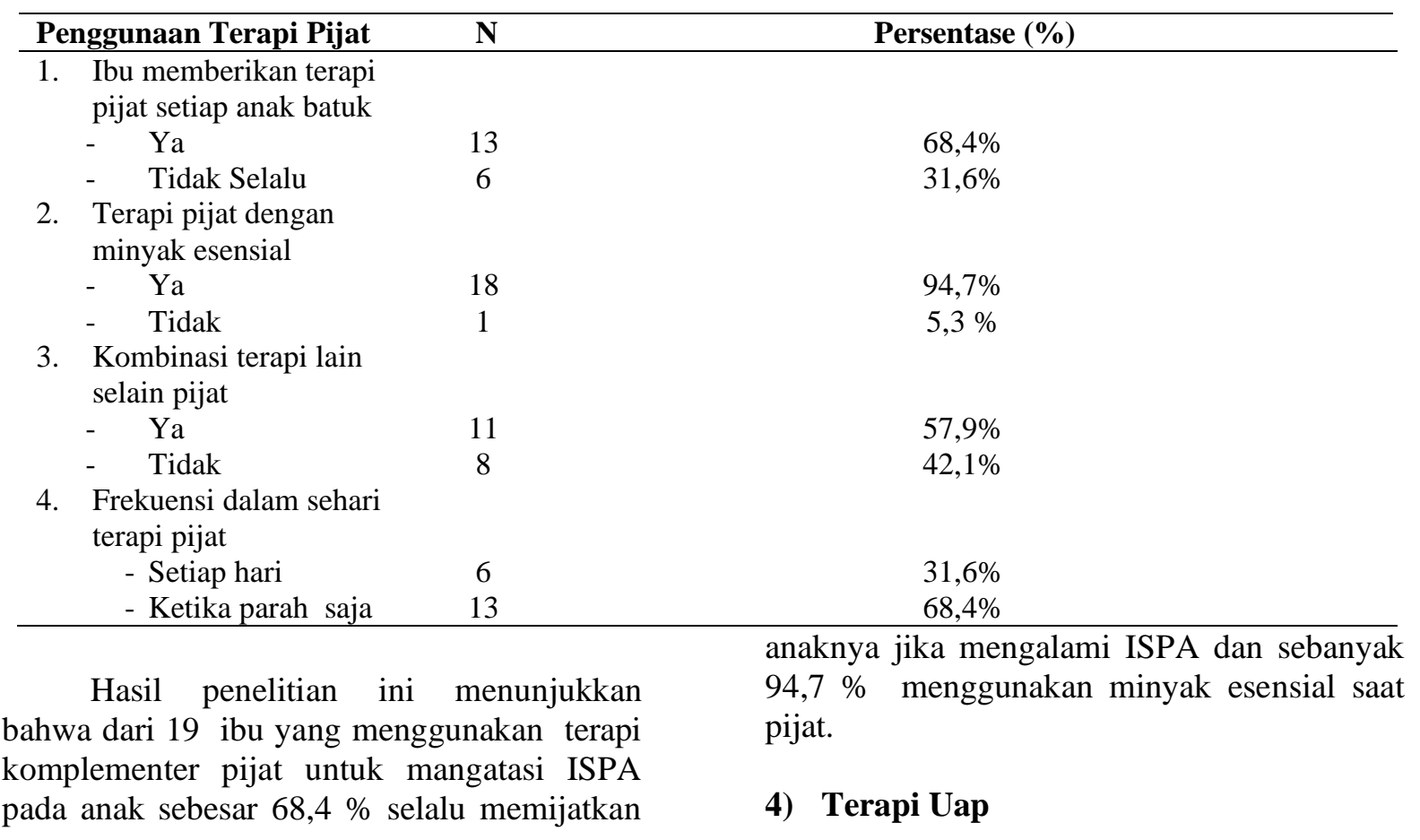

Tabel 7. Distribusi frekuensi penggunaan terapi uap $(n=9)$

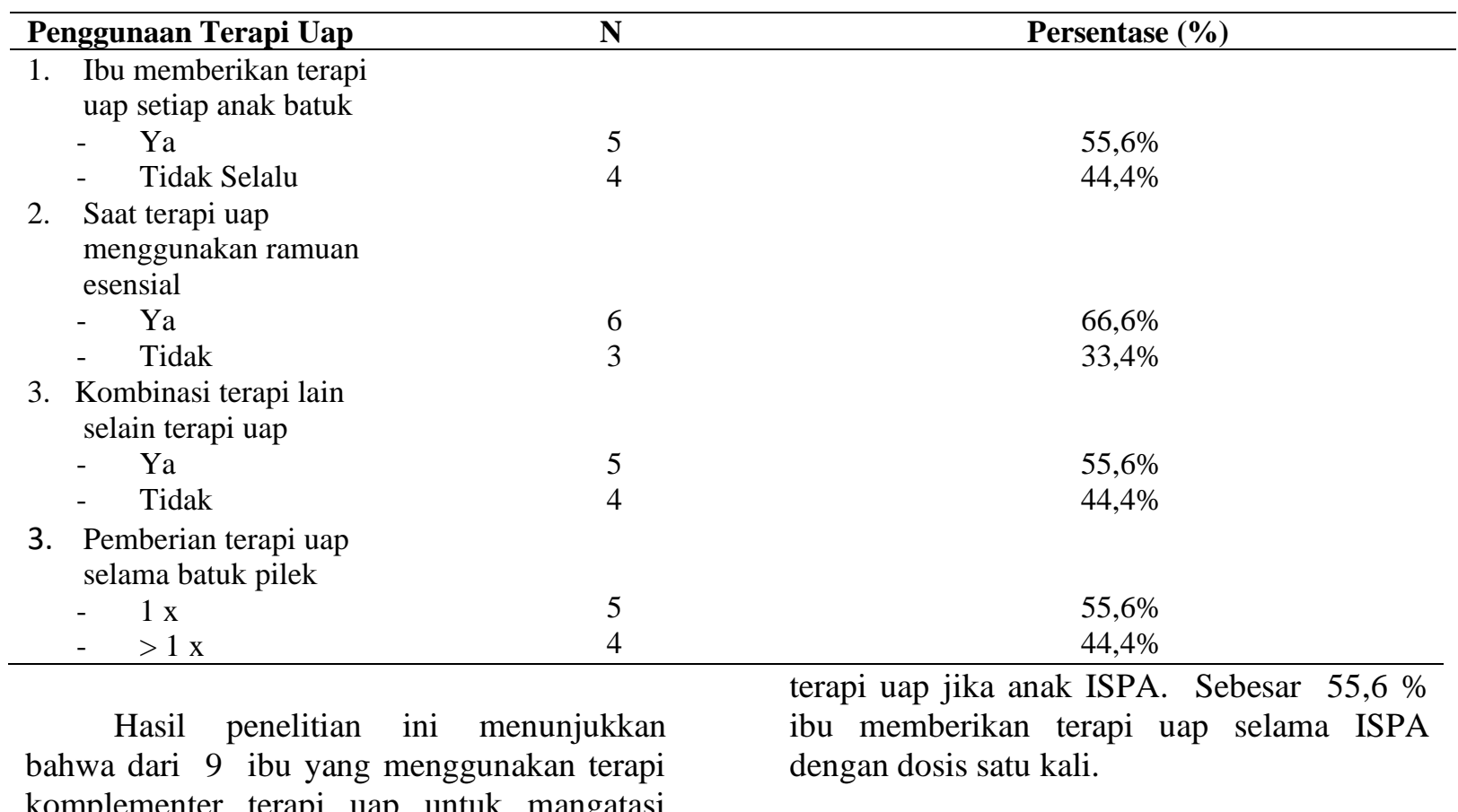

komplementer terapi uap untuk mangatasi ISPA sebanyak 55,6\% selalu menggunakan

\section{5) Kombinasi}


Tabel 8. Distribusi frekuensi penggunaan terapi komplementer kombinasi $(n=12)$

\begin{tabular}{|c|c|c|}
\hline $\begin{array}{l}\text { Penggunaan Terapi } \\
\text { Komplementer Kombinasi }\end{array}$ & $\mathbf{N}$ & Persentase (\%) \\
\hline $\begin{array}{l}\text { 1. } \begin{array}{l}\text { Larutan jahe madu } \\
\text { dan jeruk kecap }\end{array}\end{array}$ & 1 & $8,3 \%$ \\
\hline $\begin{array}{l}\text { 2. Larutan jeruk kecap } \\
\text { dan pijat }\end{array}$ & 2 & $16,6 \%$ \\
\hline 3. Pijat dan terapi uap & 2 & $16,6 \%$ \\
\hline $\begin{array}{l}\text { 4. Larutan jahe madu, } \\
\text { jeruk kecap dan pijat }\end{array}$ & 4 & $33,3 \%$ \\
\hline $\begin{array}{l}\text { 5. Larutan jahe madu, } \\
\text { pijat dan terapi uap }\end{array}$ & 2 & $16,6 \%$ \\
\hline $\begin{array}{l}\text { 6. Larutan jahe madu, } \\
\text { jeruk kecap, pijat dan } \\
\text { terapi uap }\end{array}$ & 1 & $8,3 \%$ \\
\hline
\end{tabular}

Berdasarkan tabel 4.8 menunjukkan bahwa dari 12 ibu yang menggunakan kombinasi terapi komplementer sebesar 33,3 $\%$ mengkombinakan larutan jahe madu, jeruk

c. Alasan Keluarga memilih Terapi Komplementer

\section{Tabel 9. Distribusi frekuensi alasan keluarga tertarik menggunakan terapi komplementer dalam mengatasi ISPA pada balita $(n=32)$}

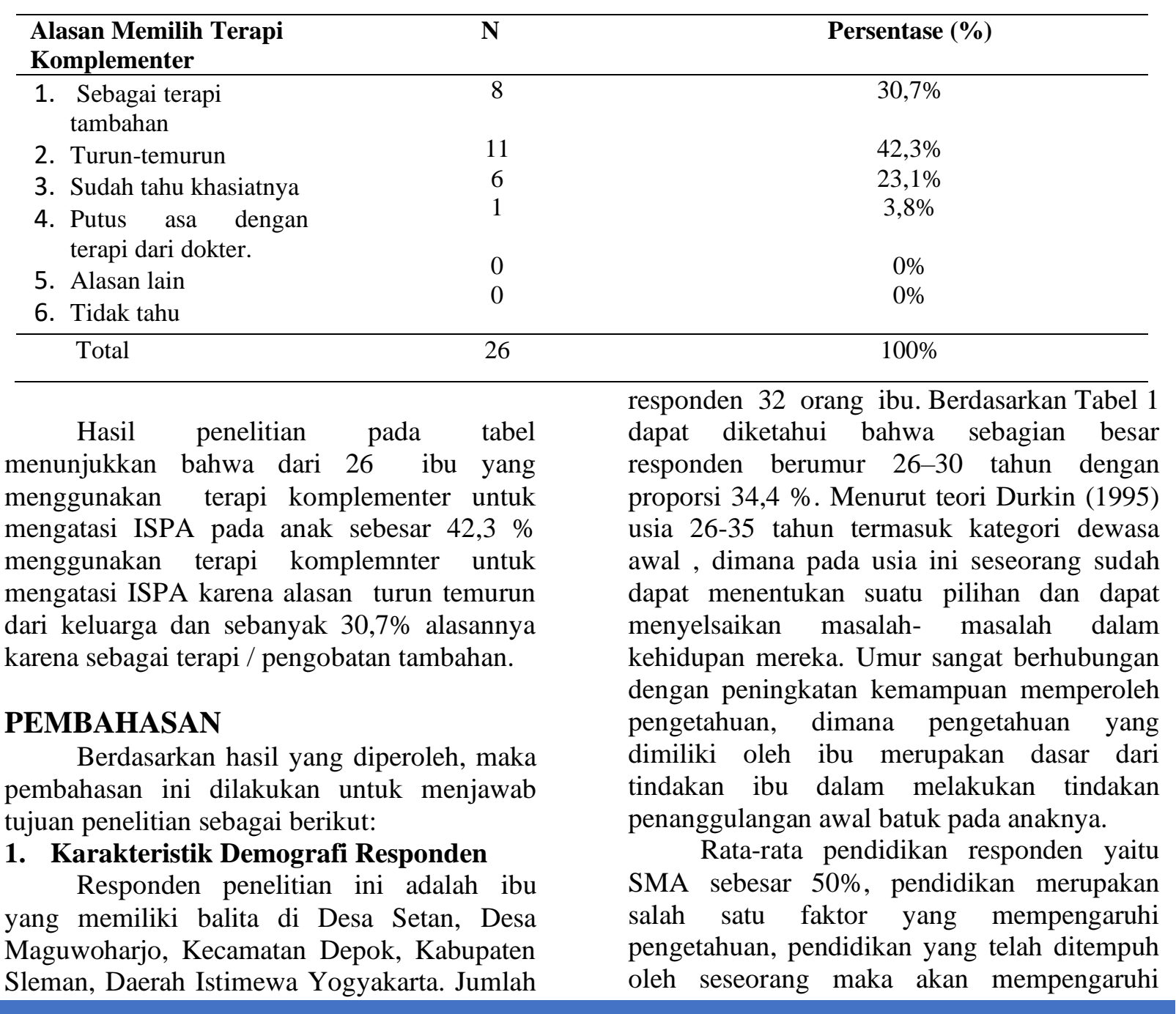


pengetahuan mereka. Menurut Notoatmodjo (2012) menjelaskan bahwa pendidikan akan berdampak pada tingkat pengetahuan seseorang.Seseorang yang memiliki pendidikan tinggi akan mempunyai wawasan yang lebih luas dibandingkan dengan seseorang yang berpendidikan lebih rendah.

Berdasarkan status pekerjaan, responden pada penelitian ini bekerja sebesar $75 \%$, sedangkan ibu yang tidak bekerja sebanyak $25 \%$. Hasil penelitian ini berbeda dengan hasil penelitian Gia Putri Sunarta di wilayah kerja Puskesmas Karangmalang Sragen dimana dari 33 responden sebanyak 21 responden ( 64\%) dengan status pekerjaan tidak bekerja atau sebagai ibu rumah tangga. Salah satu peran ibu dalam menjaga kesehatan anak adalah memperbaiki pola konsumsi anak, memperhatikan pola kebersihan anak seharihari, dan menciptakan budaya hidup bersih dan sehat pada diri anak.

\section{Penggunaan Terapi Komplementer pada Setiap Terapi}

Terapi komplementer dikenal dengan terapi tradisional yang digabungkan dalam pengobatan modern, yang dilakukan sebagai pendukung pengobatan medis konvesional atau sebagai pengobatan pilihan lain diluar pengobatan medis yang konvensional (Widaryanti R, 2019). Berdasarkan hasil penelitian di Dusun Setan, Desa Maguwoharjo, Kecamatan Depok, Kabupaten Sleman penggunaan terapi komplementer dalam mengatasi ISPA pada ibu yang memiliki balita sebagian besar $(81,2 \%)$ responden menggunakan terapi komplementer sebagai terapi untuk mengatasi ISPA pada anaknya. Pada pemilihan terapi komplementer dari 26 orang responden yang menggunakan terapi, 12 responden diantaranya menggunakan terapi komplementer secara kombinasi. Terapi kombinasi yang paling banyak digunakan pada responden Di Dusun Setan Desa Maguwoharjo, Kecamatan Depok, Kabupaten Sleman adalah kombinasi larutan jahe madu, jeruk kecap dan pijat.

Hasil penelitian ini sejalan dengan penelitian Rumahorbo di Desa Beganding Kabupaten Karo diperoleh bahwa dari 32 orang responden, 87,5 \% (28 orang) menggunakan terapi komplementer pada balita yang menderita ISPA dan $12,5 \%$ (4 orang) tidak menggunakan terapi komplementer, dan dari hasil penelitian didapat bahwa 16 orang responden $(50 \%)$ menggunakan terapi komplementer secara kombinasi.

Dalam penggunaan terapi komplementer untuk mengatasi ISPA, sebanyak 10 ibu menggunakan terapi larutan jahe dan madu sebesar $70 \%$ dengan dosis < $3 \mathrm{x}$ sehari 1 sendok teh. Tanaman jahe merupakan salah satu tanaman jenis rempah rempah berbentuk rimpang yang banyak dimanfaatkan secara tradisional sebagai minuman penghangat serta pereda batuk, nyeri dan diare. Upaya pemanfaatan ekstrak jahe untuk menghambat perrtumbuhan bakteri dan salah satu penyebab penyakit ISPA adalah mikroorganisme, namun yang terbanyak disebabkan oleh virus dan bakteri (Fathia S, 2011).

Penggunaan terapi komplementer untuk mengatasi ISPA dengan pemberian larutan jeruk dan kecap dilakukan oleh 9 ibu memberikan dengan frekuensi $3 \mathrm{x}$ sehari dengan dosis 1 sendok teh. Jeruk nipis merupakan salah satu buah yang banyak digemari oleh masyarakat di Indonesia. Jeruk nipis yang bernama latin Citrus aurantifolia ialah salah satu jenis tanaman yang banyak tumbuh dan dikembangkan di Indonesia. Selain itu jeruk nipis juga dapat digunakan untuk obat batuk, peluruh dahak, influenza, dan obat jerawat. Buah ini banyak dikonsumsi masyarakat dan mempunyai harga relatif murah, mudah diperoleh, alamiah, serta tidak menimbulkan efek samping bagi pemakainya (Adina AB, 2015). Selain itu, menurut Fajjriyah (2017) jeruk nipis juga mengandung vitamin A, kalsium sebanyak $40 \mathrm{mg} / 100 \mathrm{~g}$ jeruk, fosfor sebanyak $22 \mathrm{mg}$, lemon kamfer, belerang, vitamin B1, vitamin $\mathrm{C}$, flavonoid, asam sitrat, glikosida, asam amino, damar, asam sitrun, lemak, dan besi. Kandungan flavonoid dalam jeruk nipis berfungsi sebagai antibakteri.

Selain jeruk nipis dan jahe madu, saat ini masyarakat menggunakan terapi komplementer untuk mengatasi ISPA dengan pijat atau massage dan terapi uap. Dari keempat terapi komplementer untuk mengatasi ISPA yang peneliti tanyakan untuk pemilihan terapi komplementer, terapi pijat atau massage merupakan terapi yang paling sering digunakan keluarga dibandingkan dengan ketiga terapi lain baik secara tunggal atau kombinasi sebesar $25 \%$. 
Hasil penelitian ini sejalan dengan penelitian Sitti Aulia Dina Resmi (2016) di Desa Tabudarat Hilir Kecamatan Labuan Amas Selatan Kabupaten Hulu Sungai Tengah, Kalimantan Selatan, jenis terapi yang digunakan orang tua untuk menangani demam yang di alami balita tertinggi adalah terapi pijat semua responden berjumlah 58 orang (100\%) menggunakannya. Hasil penelitian ini menyebutkan bahwa saat anak demam responden lebih banyak menggunakan pijat karena mereka menganggap pijat dapat menurunkan demam, membuat rasa nyaman dan anak mereka tidak rewel lagi.

Terapi sentuhan atau massage (pemijatan) adalah salah satu teknik yang mengkombinasikan manfaat fisik sentuhan manusia dengan manfaat emosional seperti ikatan batin (bounding). Pemijatan ini memungkinkan kandungan-kandungan aktif minyak terserap ke dalam kulit. Minyakminyak esensial yang terserap dalam cara ini membantu meringankan infeksi-infeksi dan peradangan-peradangan karena mereka seringkali dikeluarkan dari tubuh melalui paruparu. Titik akupresur ini dilakukan peijatan setiap titiknya minimal 3 menit. (Purwanto B, 2013).

Hasil penelitian ini menunjukkan bahwa orang responden yang hanya menggunkan terapi pijat dan terdapat 11 responden yang menggunakan terapi pijat secara kombinasi. Dari 19 ibu yang menggunakan terapi komplementer pijat untuk mangatasi ISPA pada anak sebesar $68,4 \%$ selalu memijatkan anaknya jika mengalami ISPA dan sebanyak 94,7\% menggunakan minyak esesial saat pijat. Sebesar 31,6\% memijatkan anaknya setiap hari saat anak mengalami ISPA. Sebesar 57,9\% ibu mengkombinasikan terapi komplementer pijat dengan terapi komplementer lainnya.

Hasil penelitian ini berbeda dengan hasil yang didapat dari penelitian Rumahorbo di Desa Beganding Kabupaten Karo dimana dia mendapatkan terapi sembur merupakan pilihan terapi mayoritas responden untuk mengatasi ISPA pada balita, dan terapi kedua terbanyak yang dipilih adalah terapi sentuhan atau pemijatan. Obat tradisional sembur masih sangat akrab dengan masyarakat Karo. Terapi sembur merupakan obat yang terdiri dari beras, daun-daunan hutan, jahe, lada, jerangan, pala, dan akar-akaran dari tanaman obat yang semuanya digongseng kemudian ditumbuk tidak terlalu halus. Cara penggunaannya yaitu dengan menyemburkan ke bagian tubuh yang dianggap perlu. Sembur ini memiliki manfaat yang antara lain mengobati masuk angin, sakit perut, demam, panas dalam dan flu.

Pilihan terapi komplementer kedua di Dusun Setan selain pijat adalah dengan memberikan terapi uap. Terapi uap merupakan terapi menggunakan air panas. Uap air dan mandi air panas adalah cara menyembuhkan flu yang paling umum. Beberapa orang berdiri di kamar mandi dengan siraman air panas tetapi ada juga yang menghirup uap di atas panci dengan air mendidih. Tindakan ini memiliki sejumlah efek terapeutik, di antaranya berguna untuk mengencerkan lendir di saluran hidung dan sinus serta di bawah saluran pernapasan (Nuraeni, 2012). Cara pemberian terapinya adalah dengan menuangkan air panas ke dalam panci/baskom tahan panas. Lalu tutup kepala dengan menggunakan handuk kecil dan kepala didekatkan di atas baskom dan kumpulkan uap dan hiruplah dalam-dalam. Terapi ini juga boleh ditambahkan dengan mencampurkan minyak-minyak atau herbalherbal segar seperti pepermint atau Asian mint.

Dari 9 ibu yang menggunakan terapi komplementer terapi uap untuk mangatasi ISPA sebanyak 55,6\% selalu menggunakan terapi uap jika anak ISPA. Sebesar 55,6\% ibu memberikan terapi uap selama ISPA dengan dosis satu kali. Terapi uap merupakan salah satu cara yang diperkenalkan dalam penggunaan metode terapi yang paling sederhana dan cepat. Cara kerja dari inhalasi adalah uap masuk dari luar tubuh ke dalam tubuh dengan mudah akan melewati paru-paru dialirkan ke pembuluh darah melalui alveoli. Terapi uap maka pasien akan menghirup uap dengan atau tanpa obat melalui saluran pernapasan bagian atas, dalam hal ini merupakan tindakan untuk membuat pernapasan lebih lega, sekret lebih encer dan mudah dikeluarkan, selaput lendir pada saluran napas menjadi tetap lembab (Mubarak, Indarawati dan Susanto, 2015)

\section{Alasan Keluarga memilih Terapi Komplementer}

Hasil penelitian ini juga menunjukkan bahwa mayoritas responden memilih terapi komplementer memiliki alasan. Secara total ada 26 responden yang memilih menggunakan 
terapi komplementer sebagai terapi tambahan dari pengobatan medis memiliki alasan karena sudah turun temurun dari keluarga sebesar 42,3 $\%$ dan sebanyak 30,7\% alasannya karena sebagai terapi / pengobatan tambahan.

Dalam penelitian Freda (2001) menunjukkan bahwa ketertarikan kepada CAM (Complementary Alternative Medicine) dan menggunakannya secara pribadi tidak memiliki hubungan dengan pengetahuan yang mereka miliki. Sedikit pengetahuan tentang CAM tetap memacu mereka untuk menggunakan dan lebih merasakan kepuasan menggunakan CAM dibandingkan dengan pengobatan konvensional.

\section{SIMPULAN DAN SARAN Simpulan}

Mayoritas anggota keluarga memberikan terapi komplementer pada balita saat mengalami ISPA dengan persentase 81,2 $\%$ dengan pemilihan terapi terbanyak yaitu terapi pijat secara tunggal sebesar $25 \%$ dan secara kombinasi sebesar $73,1 \%$. Cara penggunaan terapi tidak menggunakan aturan yang pasti, hanya ketika balita mengalami batuk pilek keluarga akan memberikan sesuai kebutuhan hingga balita sembuh. Alasan terbanyak responden menggunakan terapi komplementer untuk mengatasi ISPA adalah karena sudah menggunakan secara turun temurun dalam keluarga sebanyak $42,3 \%$.

\section{Saran}

Diharapkan bagi peneliti selanjutnya menggunakan desain kualitatif untuk mengkaji lebih dalam penggunaan terapi komplementer dalam mengatasi ISPA di masyarakat.

\section{DAFTAR PUSTAKA}

Adina AB, Handoko FF, Setyarini II. 2015."Jeruk Nipis (Citrus aurantifolia)" CCRC Farmasi UGM. Yogyakarta

Amir, Amri, Hanafiah, Jusuf. 2009. Etika Kedokteran dan Hukum Kesehatan Edisi 4. EGC. Jakarta

Badan Pusat Statistik. 2017. Survei Demografi Kesehatan Indonesia Tahun 2017. BPS. Jakarta

Bezerra PGM, Britto MCA, Correia JB, Duarte $\mathrm{M}$ do CMB, Fonceca AM, Rose K, et al. 2011.Viral And Atypical Bacterial Detection In Acute Respiratory Infection
In Children Under Five Years. PLoS One [Internet];6(4):e18928. Available from: http://

www.pubmedcentral.nih.gov/articlerend er.fcgi?artid=3078930\&tool=pmcentrez \&rendert ype $=$ abstract

Depkes RI. 2003. Kepmenkes nomor 1076/MENKES/SK/VII/2003 tentang penyelengaraan pengobatan tradisional definisi pengobatan komplementer tradisional- alternatif. DepKes RI. Jakarta.

DepKes RI. 2010.Pengobatan Komplementer Tradisional- Alternatif. Depkes. Jakarta. [diunduh 23 Oktober 2010]. Tersedia dari: http://www.yanmedik.depkes.go.id

Durkin, Kevin. 1995. Developmental Social Psychology : From Infancy to Old Age New Jersey: Wiley Blackwell

Evans. H., Tuleu. C., Sutcliffe. A.2010. Is honey a well-evidenced alternative $t i$ over-the-counter cough medicines. Journal of R Social Medicine, 103, 164165.

Fajjriyah, Noor. 2017. Kiat Sukses Budidaya Bawang Merah. Penerbit Bio Genesis. Yogyakarta

Fathia S, 2011. Aktivitas Antimikroba Ekstrak Jahe (Zingiber Officinale Roscoe) Terhadap Beberapa Bakteri Patogen. Skripsi.Bogor. Institut Pertanian Bogor.

Freda DeKeyser, Hadassah-Hebrew .2001. Knowledge Levels And Attitudes Of Staff Nurses In Israel Towards Complementary And Alternative Medicine.University School of Nursing, Kiryat Hadassah

Gia Putri Sunarta. 2018. Gambaran Perilaku Ibu Terhadap Penanganan Batuk Pada Balita Dengan ISPA. Skripsi.Program Studi S1 Keperawatan Fakultas Ilmu Kesehatan Universitas Muhammadiyah Surakarta

Mubarak, Indrawati dan Susanto. 2015. Buku 1 Ajar Ilmu Keperawatan Dasar. Salemba Medika.Jakarta.

Nuraini, Ade. 2012. Pengaruh Steam Inhalation Terhadap Usaha Bernapas Pada Balita Dengan Pneumonia Di Puskesmas Kabupaten Subang Provinsi Jawa Barat. Tesis Program Magister Ilmu Keperawatan. Universitas Indonesia. Jakarta.Diakses pada 13 
Oktober 2019, Tersedia dari http://lib.ui.ac.id

Notoatmodjo S. 2012. Promosi Kesehatan dan Perilaku Kesehatan. PT Rineka Cipta.Jakarta.

Pavia AT. 2011. Viral Infections of the Lower Respiratory Tract: Old Viruses, New Viruses, and the Role of Diagnosis. Clin Infect Dis [Internet]. 2011;52(4):284-9. Available from: http://cid.oxfordjournals.org/content/52/ suppl_4/S284.full.pdf+html

Purwanto B.2013. Ragam Terapi Kesehatan Berbasis Herbal. Gosyen Publishing. Karanganyar

Ramadhani, A. N.2014. Efektifitas pemberian minuman jahe madu terhadapkeparahan batuk pada anak dengan ISPA. Universitas Riau. Diakses pada 13 Januari 2020 dari situs http://download.portalgaruda.org/

Rumahorbo, Adventy Tersania. 2016. Terapi Komplementer Dalam Mengatasi ISPA pada Keluarga yang Memiliki Balita di Desa Beganding Kabupaten Karo. Skripsi. Fakultas Keperawatan Universitas Sumatra Utara.Medan.

Sitti Aulia Dina Resmi, Evi Risa Mariana, Bahrul Ilmi. 2016. Persepsi Orang Tua Terhadap Terapi Komplementer Dalam Penanganan Demam Pada Balita Di Desa Tabudarat Hilir Kec. Las Kab. Hst.Jurnal Citra Keperawatan, Vol 5 No 1 (2017), 19-25

Shadkam, M.N., Mozaffari-Khosravi, H., \& Mozayan, M.R. 2009. A comparison ofthe effect of honey, Dextromethorphan and Diphenhydramine on nightly coughand sleep quality in children and their parents. The Journal of Alternative and Complementary Medicine, 16 (7), 787-793.

Widaryanti R, Riska H. 2019. Terapi Komplementer Pelayanan Kebidanan. Deep Publish. Yogyakarta.

World Health Organization.2015. World Health Statistics 2015. WHO Press. 